\title{
Upaya Peningkatan Kewaspadaan Universal Bagi Petugas Puskesmas
}

\author{
Neti Juniarti, Hartiah Haroen, Raini Diah Susanti \\ Fakultas Keperawatan Universitas Padajdaran \\ Email: neti.juniarti@unpad.ac.id
}

\begin{abstract}
Abstrak
AIDS (Acquired Immuno Deficiency Syndrome) merupakan sindrom penyakit dengan angka kematian yang cukup tinggi menyebabkan penyakit ini sangat ditakuti oleh masyarakat.Meningkatnya prevalensi HIV/AIDS berarti meningkat pula resiko tenaga kesehatan yang dapat tertular HIV/AIDS, khususnya bila kewaspadaan terhadap darah dan cairan tubuh tidak dilaksanakan terhadap semua pasien.Mengingat pentingya pelaksanaan kewaspadaan universal (universal precaution) bagi tenaga kesehatan maka upaya peningkatan kewaspadaan universal bagi tenaga puskesmas menjadi landasan utama dalam Pengabdian Masyarakat ini. Pengabdian kepada masyarakat ini dilaksanakan di Puskesmas Jatinangor Kecamatan Cikeruh Kabupaten Sumedang. Peserta yang hadir sebanyak 31 orang. Kegiatan ini bertujuan untuk meningkatkan pelaksanaan tindakan kewaspadaan universal (universal precaution) bagi petugas Puskesmas Jatinangor sebagai upaya mencegah penularan HIV/AIDS pada tenaga kesehatan. Dengan adanya kegiatan PKM ini diharapkan dapat memberikan manfaat baik bagi petugas puskesmas maupun bagi masyarakat untuk mencegah penularan HIV/AIDS di wilayah Jatinangor khususnya, dan di Kab. Sumedang pada umumnya. Rancangan kegiatan upaya peningkatan kewaspadaan adalah pemberian edukasi dengan pretest dan posttest disain yang dilakukan pada petugas puskesmas yang berjumlah 31 orang. Hasil kegiatan penyuluhan ini berhasil untuk meningkatkan pengetahuan dan sikap petugas kesehatan tentang kewaspadaan universal, hal ini terbukti dari peningkatan hasil pre test tingkat pengetahuan $60 \%$ menjadi $100 \%$ pada saat post test. Untuk sikap pada saat pre test $6,25 \%$ menyatakan sangat setuju dan 18,75\% menyatakan setuju bahwa memakai sarung pada saat melakukan tindakan merepotkan. Setelah post test masih ada $8 \%$ peserta yang menyatakan bahwa memakai sarung tangan merepotkan. Sebanyak 44\% menyatakan tidak setuju dan 56\% menyatakan sangat tidak setuju kalau memisahkan sampah medis dan non medis merepotkan. Simpulan kegiatan pengabdian masyarakat ini telah meningkatkan pengetahuan dan sikap hampir seluruh petugas kesehatan di Puskesmas.
\end{abstract}

Kata kunci: HIV/AIDS, kewaspadaan universal, pendidikan kesehatan.

\begin{abstract}
AIDS (Acquired Immune Deficiency Syndrome) is a disease syndrome with high mortality rate in the community. The increased of HIV/AIDS prevalence in the community also increase the risk of HIV infection for health professionals in community health centers particularly if they do not perform universal precaution towards blood and other body fluid of patients. Thus, universal precaution is very important for community health centers personnel. Therefore, this community service was conducted in Puskesmas Jatinangor in order to improve the capacity of health professionals in this center to implement universal precaution. Health professionals who attended this event were 31 people. With this community service activity, it was expected that health professionals can prevent the spreading of HIVIAIDS as well as to protect people in the community from the disease. The results showed that knowledge and attitude of health professionals about universal precaution in Puskesmas Jatinangor were improved after the health education. The score of post test compared to pre-test of universal precaution knowledge was improved from $60 \%$ to $100 \%$. For the attitude, $44 \%$ and 56\% participants disagreed and strongly disagree respectively that separating medical and non-medical waste were bothersome. However there were $8 \%$ of participants expressed that wearing gloves were disturbing their activities.
\end{abstract}

Key words: HIV/AIDS, health education, universal precaution. 
Neti Juniarti : Upaya Peningkatan Kewaspadaan Universal Bagi Petugas Puskesmas

\section{Pendahuluan}

AIDS (Acquired Immuno Deficiency Syndrome) adalah suatu gejala berkurangnya kemampuan pertahanan diri yang disebabkan oleh masuknya virus HIV kedalam tubuh manusia (Depkes RI, 2005). Secara global, terdapat 36,9 juta orang hidup dengan HIV di tahun 2017 dan hanya 59\% yang mendapatkan terapi antiretroviral (WHO, 2017). Di Indonesia, diperkirakan terdapat 630.000 orang hidup dengan HIV/AIDS pada tahun 2015 dan dari jumlah ini hanya 9\% yang mendapatkan terapi antiretroviral (WHO, 2017). AIDS merupakan sindrom penyakit dengan resiko kematian yang tinggi. Pada tahun 2017, di dunia terdapat 900 ribu orang meninggal karena kondisi yang berhubungan dengan HIV (WHO, 2017). Tingginya angka kematian AIDS, ditambah lagi dengan belum ditemukannya obat yang efektif untuk membunuh virus HIV menyebabkan penyakit ini sangat ditakuti oleh masyarakat (Sugiharti, Yuniar, \& Lestary 2014).

Penyebab utama penyebaran virus HIV diantaranya : perilaku seks bebas sebagai transmisi utama HIV/AIDS; penyalahgunaan narkoba yang umumnya tertular melalui penggunaan jarum suntik bersama dan aktif melakukan seks bebas; penularan HIV/AIDS sebagai akibat "Efek Spiral" perilaku seks bebas yaitu melalui transfusi darah, ASI, alat-alat kedokteran, hubungan suami istri yang sudah tertular virus HIV positif; penularan virus HIV melalui Orang dengan HIV/AIDS yang dapat terjadi apabila ada kontak antara cairan tubuh ODHA (terutama darah, semen, sekresi vagina dan ASI) dengan luka terbuka pada seseorang yang sehat walaupun kecil. Seseorang yang mengidap penyakit ini dapat menularkan virusnya kepada orang lain jika darah atau cairan tersebut masuk kedalam darah orang lain melalui luka atau produk darah atau tranfusi (Oktarina, Hanafi, \& Budisuari, 2009).

Meningkatnya prevalensi HIV/AIDS berarti meningkat pula resiko tenaga kesehatan yang dapat tertular HIV/AIDS, khususnya bila kewaspadaan terhadap darah dan cairan tubuh tidak dilaksanakan terhadap semua pasien. Tenaga kesehatan perlu mempertimbangkan bahwa semua pasien berpotensi terinfeksi penyakit HIV/AIDS maupun penyakit menular lainnya, serta perlu menerapkan kewaspadaan universal meminimalkan risiko penularan dari darah dan cairan tubuh semua pasien. Pekerja sektor kesehatan ketika memberikan perawatan kepada pasien HIV/AIDS memiliki risiko mendapat penularan, khususnya bila aturan-aturan dasar keselamatan dan kewaspadaan universal tidak dilaksanakan.

Di Jawa Barat jumlah kumulatif kasus HIV/AIDS dilaporkan periode Januari sampai dengan Maret 2007 sebanyak 1.105 orang dengan kematian sebanyak 173 orang. Hingga tahun 2016, jumlah kasus HIV AIDS di Jawa Barat sudah mencapai lebih dari 21 ribu kasus, dan kecenderungannya terus meningkat (Dinas Kesehatan Provinsi Jawa Barat, 2018). Dari data Dinas Kesehatan Kabupaten Sumedang pada April 2006 didapat penderita HIV/AIDS mencapai 25 orang, bahkan 3 diantaranya 
sudah meninggal dunia karena AIDS. Dan terus meningkat sampai bulan Agustus 2007 berjumlah 46 orang dan maninggal dunia 7 orang. Pada tahun 2016 penderita HIV/AIDS di Kabupaten Sumedang tercatat 375 penderita. Di antaranya 201 penderita, di laporkan sudah meninggal dunia, sedangkan sekitar 90 orang masih menjalani pengobatan (KPAD. 2016). Penularan virus HIV/AIDS terhadap masyarakat di Kabupaten Sumedang, tampaknya harus segera mendapat perhatian dan penanggulangan dari pemerintah dan semua komponen masyarakat (Dinkes Kab. Sumedang 2006).

Dari data Dinas Kesehatan Kabupaten Sumedang terdapat 32 puskesmas yang ada di daerah Kabupaten Sumedang. Delapan Puskesmas diantaranya merupakan daerah yang menjadi titik rawan penyakit HIV/AIDS (Dinkes Kab. Sumedang 2006). Dua puskesmas pernah merujuk pasien dengan kasus HIV (+) sedangkan sisanya merupakan kelompok yang lingkungannya berdekatan dengan lokalisasi pekerja seksual komersial (PSK) termasuk diantaranya adalah Puskesmas Jatinangor. Berdasarkan hasil studi pendahuluan di Puskesmas Jatinangor Kecamatan Cikeruh ternyata 48,2\% petugas puskesmas memiliki bersikap kurang mendukung terhadap tindakan universal precaution ini, dan 45,4\% petugas puskesmas kurang melaksanakan tindakan universal precaution dengan benar.

Dampak penyakit HIV/AIDS bagi tenaga kesehatan sangat penting karena tingginya risiko penularan dari pasien jika tidak melakukan tindakan kewaspadaan secara tepat. Tenaga kesehatan merupakan tenaga yang beperan penting dan berada pada garis depan dalam penanggulangan HIV/AIDS. Jika tenaga kesehatan tidak mendapatkan perawatan, maka proporsi kematian karena kasus HIV/AIDS kemungkinan akan semakin meningkat.

Berdasarkan uraian pada pendahuluan dan analisis situasi, maka penulis dapat menyimpulkan bahwa upaya peningkatan kewaspadaan universal bagi tenaga puskesmas di Puskesmas Jatinangor perlu dilakukan sehingga dapat mencegah terjadinya penularan HIV/AID di masyarakat. Jadi, perumusan masalah dalam penelitian ini adalah "bagaimana pengaruh upaya peningkatan pelaksanaan tindakan kewaspadaan universal terhadap pengetahuan dan sikap bagi petugas Puskesmas Jatinangor, Kecamatan Cikeruh, Kab. Sumedang, Propinsi Jawa Barat".

Tujuan pengabdian pada masyarakat ini adalah untuk meningkatkan pengetahuan dan sikap kewaspadaan universal (universal precaution) bagi petugas Puskesmas Jatinangor sebagai upaya mencegah penularan HIV/AIDS pada tenaga kesehatan. Adapun tujuan khusus dari kegiatan ini antara lain:

1. Mengidentifikasi pengetahuan dan sikap petugas kesehatan tentang tindakan universal precaution di Puskesmas Jatinangor Kecamatan Cikeruh, Kab. Sumedang, Propinsi Jawa Barat. 
Neti Juniarti : Upaya Peningkatan Kewaspadaan Universal Bagi Petugas Puskesmas

2. Mengidentifikasi komponen universal precaution yang belum dilaksanakan dengan baik oleh petugas Puskesmas Jatinangor Kecamatan Cikeruh, Kab. Sumedang, Propinsi Jawa Barat.

3. Melakukan pelatihan tindakan universal precaution bagi petugas di Puskesmas Jatinangor Kecamatan Cikeruh, Kab. Sumedang, Propinsi Jawa Barat.

4. Melakukan evaluasi pelaksanaan tindakan universal precaution di di Puskesmas Jatinangor Kecamatan Cikeruh, Kab. Sumedang, Propinsi Jawa Barat.

\title{
Metode
}

Rancangan kegiatan pengabdian pada masyarakat ini adalah upaya peningkatan kewaspadaan universal dengan pendekatan desain pretest, edukasi, simulasi dan praktik serta posttest yang dilakukan pada petugas puskesmas yang berjumlah 31 orang. Kelompok sasaran dalam kegiatan ini adalah tenaga kesehatan yang terdiri dari berbagai profesi seperti perawat, perawat gigi, dokter, dokter gigi, petugas lab, tenaga kesehatan lingkungan, petugas gizi dan petugas cleaning service. Metode kegiatan terdiri dari pre-test untuk mengukur pengetahuan dan sikap tenaga kesehatan tentang kewaspadaan universal, setelah itu dilanjutkan dengan pemberian materi, simulasi dan praktik, kemudian diakhiri dengan posttest. Untuk mengukur perubahan pengetahuan dan sikap petugas kesehatan digunakan kuesioner tentang pengetahuan dan sikap yang dikembangkan dari pedoman kewaspadaan universal dari Badan Kesehatan Dunia (WHO, 2007)

\begin{abstract}
. Analisa data menggunakan analisis deskriptif.
pelaksanaan kegiatan pengabdian kepada masyarakat dilakukan pre-test dan post-test untuk mengetahui kemampuan awal peserta dan perubahannya setelah diberikan pelatihan. Kemampuan yang diukur adalah pengetahuan petugas kesehatan tentang kewaspadaan universal, sikap petugas kesehatan terhadap kewaspadaan universal, dan tindakan kewaspadaan universal.
\end{abstract}

\section{Hasil}

Berdasarkan hasil pre-test diketahui bahwa skor terendah adalah 60 yang didapat oleh 6,25\% peserta dan skor tertinggi adalah 80 yang didapat oleh $93,75 \%$ peserta. Item pertanyaan yang terbanyak dijawab salah adalah pertanyaan tentang apa yang harus dilakukan oleh petugas kesehatan jika menderita penyakit menular. Berdasarkan hasil post-test diperoleh data bahwa $60 \%$ peserta memperoleh skor tertinggi (100) dan $8 \%$ peserta memperoleh skor terendah 40. Peningkatan tertinggi adalah sebanyak 40 point. Walaupun sebagian besar peserta mengalami peningkatan pengetahuan, akan tetapi masih ada $8 \%$ peserta yang memiliki pengetahuan kurang setelah diberikan pelatihan. Hal ini kemungkinan terjadi karena sebagian peserta kurang fokus mengikuti kegiatan pelatihan karena masih harus melayani pasien sehingga beberapa orang peserta harus meninggalkan ruangan pelatihan untuk beberapa saat dan kembali lagi pada saat post-test dilakukan. 
Neti Juniarti : Upaya Peningkatan Kewaspadaan Universal Bagi Petugas Puskesmas

Pada aspek sikap, secara umum terdapat perubahan sikap peserta pelatihan terhadap kegiatan kewaspadaan universal. Hal ini dapat terlihat dari persentase perubahan sikap yang diperoleh pada pre-test dan post-test yang terdapat pada tabel 1 dan 2 berikut ini.

Tabel 1. Hasil Pre-test Sikap Petugas terhadap Kewaspadaan Universal di Puskesmas Jatinangor

\begin{tabular}{llllll}
\hline & & \multicolumn{3}{c}{ PRE-TEST } \\
\cline { 3 - 6 } NO. & \multicolumn{1}{c}{ PERNYATAAN SIKAP } & $\begin{array}{c}\text { Sangat } \\
\text { setuju }\end{array}$ & Setuju & $\begin{array}{c}\text { Tidak } \\
\text { Setuju }\end{array}$ & $\begin{array}{c}\text { Sangat } \\
\text { tidak } \\
\text { setuju }\end{array}$ \\
\hline 1. & $\begin{array}{l}\text { Mencuci tangan sebelum merawat pasien sangat } \\
\text { penting }\end{array}$ & $81.25 \%$ & $18.75 \%$ & $0 \%$ & $0 \%$ \\
2. & $\begin{array}{l}\text { Mencuci tangan setelah terkena cairan tubuh } \\
\text { pasien }\end{array}$ & $100 \%$ & $0 \%$ & $0 \%$ & $0 \%$ \\
3. $\quad \begin{array}{l}\text { Memakai sarung tangan pada waktu } \\
\text { melaksanakan tindakan merepotkan }\end{array}$ & $6.25 \%$ & $18.75 \%$ & $25 \%$ & $50 \%$ \\
4. $\quad \begin{array}{l}\text { Merasa tidak nyaman memakai sarung tangan } \\
\text { saat menangani linen tercemar darah }\end{array}$ & $0 \%$ & $0 \%$ & $25 \%$ & $75 \%$ \\
5. $\quad \begin{array}{l}\text { Yakin bahwa menutup kembali spuit bekas } \\
\text { pakai dengan satu tangan dapat mengurangi } \\
\text { risiko tertusuk }\end{array}$ & $18.75 \%$ & $75 \%$ & $6.25 \%$ & $0 \%$ \\
6. & $\begin{array}{l}\text { Pemisahan limbah padat medis dan non medis } \\
\text { merepotkan }\end{array}$ & $6.25 \%$ & $12.50 \%$ & $37.50 \%$ & $43.75 \%$ \\
\hline
\end{tabular}

Berdasarkan Tabel 1 di atas, diketahui bahwa masih ada petugas kesehatan yang berpendapat bahwa memakai sarung tangan pada waktu melaksanakan tindakan merepotkan $(6,25 \%$ sangat setuju dan 18,75\% setuju); 6,25\% petugas menyatakan tidak setuju bahwa menutup kembali spuit bekas pakai dengan satu tangan dapat mengurangi risiko tertusuk; dan total $18,75 \%$ petugas menyatakan bahwa pemisahan limbah padat medis dan medis merepotkan. Adanya sikap yang seperti ini dapat menjadi faktor predisposisi bagi petugas kesehatan untuk tidak menggunakan sarung tangan pada saat melaksanakan tindakan, tidak menutup spuit bekas pakai dengan satu tangan, dan tidak memisahkan limbah padat medis dan non medis.

Setelah dilakukan kegiatan pelatihan dalam rangka kegiatan pengabdian masyarakat, didapatkan perubahan sikap petugas kesehatan di Puskesmas Jatinangor yang dapat dilihat pada Tabel 2

Tabel 2. Hasil Post-test Sikap Petugas terhadap Kewaspadaan Universal di Puskesmas Jatinangor

\begin{tabular}{llcccc}
\hline & \multicolumn{1}{c}{ PERNYATAAN SIKAP } & \multicolumn{3}{c}{ POST-TEST } \\
\cline { 3 - 5 } NO. & $\begin{array}{c}\text { Sangat } \\
\text { setuju }\end{array}$ & Setuju & $\begin{array}{c}\text { Tidak } \\
\text { Setuju }\end{array}$ & $\begin{array}{c}\text { Sangat } \\
\text { tidak } \\
\text { setuju }\end{array}$ \\
\hline $1 . \quad \begin{array}{l}\text { Mencuci tangan sebelum merawat pasien sangat } \\
\text { penting }\end{array}$ & $92.00 \%$ & $8.00 \%$ & $0 \%$ & $0 \%$ \\
\hline
\end{tabular}


Neti Juniarti : Upaya Peningkatan Kewaspadaan Universal Bagi Petugas Puskesmas

2. Mencuci tangan setelah terkena cairan tubuh pasien

3. Memakai sarung tangan pada waktu melaksanakan

$96 \% \quad 4 \% \quad 0 \% \quad 0 \%$ tindakan merepotkan

4. Merasa tidak nyaman memakai sarung tangan saat menangani linen tercemar darah

5. Yakin bahwa menutup kembali spuit bekas pakai dengan satu tangan dapat mengurangi risiko tertusuk

6. Pemisahan limbah padat medis dan non medis merepotkan

$8.00 \% \quad 8.00 \% \quad 44 \% \quad 40 \%$

$0 \% \quad 0 \% \quad 28 \% \quad 72 \%$

$84.00 \% \quad 16 \% \quad 0.00 \% \quad 0 \%$

$0.00 \% \quad 0.00 \% \quad 44.00 \% \quad 56.00 \%$

Berdasarkan Tabel 2 diketahui bahwa sikap petugas kesehatan sudah mulai berubah yang ditandai dengan semua peserta yang menyatakan yakin menutup spuit bekas pakai dengan satu tangan dapat mengurangi risiko tertusuk dan tidak ada yang menyatakan bahwa memisahkan limbah pada medis dan non medis merepotkan.

\section{Pembahasan}

Hasil pre-test menunjukkan bahwa pengetahuan tenaga kesehatan tentang kewaspadaan universal masih relative rendah. Hal ini sejalan dengan hasil penelitian Janjua, Razaq, Chandir, Rozi, \& Mahmood (2007) di Pakistan yang menunjukkan bahwa pengetahuan tenaga kesehatan masih sangat rendah dengan rata-rata 3,8 dan median 4 dari skor maksimal 10. Hal ini menunjukkan perlu adanya kegiatan edukasi yang dapat meningkatkan pengetahuan tenaga kesehatan tentang kewaspadaan universal. Berdasarkan hasil post-test menunjukkan bahwa pengetahuan tenaga kesehatan meningkat $100 \%$ setelah diberikan edukasi dan simulasi kewaspadaan universal di Puskesmas.

Dengan adanya perubahan sikap ini maka akan menjadi predisposisi untuk dapat melakukan tindakan kewaspadaan universal yang baik. Walaupun sudah terdapat perubahan sikap pada sebagian besar komponen yang diukur, akan tetapi masih ada peserta yang menyatakan bahwa memakai sarung tangan pada waktu melaksanakan tindakan merepotkan (8\% menyatakan sangat setuju dan $8 \%$ setuju). Hal ini dimungkinkan terjadi karena perubahan sikap ditunjang dengan perubahan pengetahuan ( $\mathrm{Li}, \mathrm{Lin}, \mathrm{Wu}, \mathrm{Guan}, \mathrm{Jia}, \&$ Yan, 2011). Pada kegiatan pelatihan ini masih ada $8 \%$ peserta yang memiliki skor pengetahuan 40 sehingga mempengaruhi sikap yang tidak mendukung terhadap pelaksanaan tindakan kewaspadaan universal. Hal ini masih lebih tinggi daripada hasil penelitian Sadoh, Fawole, Sadoh, Oladimeji, \& Sotiloye (2006) yang menunjukkan bahwa 63,8\% tenaga kesehatan selalu menggunakan alat pelindung diri. Hasil penelitian Kermode et al. (2005) juga menunjukkan bahwa pengetahuan dan sikap tenaga kesehatan yang berada di pedesaan tentang kewaspadaan universal masih parsial. Upaya peningkatan kewaspadaan universal melalui metode edukasi dan simulasi telah meningkatkan pengetahuan dan sikap petugas kesehatan di Puskesmas terhadap pelaksanaan kewaspadaan universal. 
Berhubung keterbatasan waktu dari petugas puskesmas, pre-test dan post-test praktek melakukan tindakan kewaspadaan universal hanya dilakukan pada tiga orang peserta. Berdasarkan hasil pre-test observasi tindakan kewaspadaan universal diperoleh data bahwa $50 \%$ responden tidak menutup spuit bekas pakai dengan satu tangan, dan belum melakukan tindakan cuci tangan dengan baik.Setelah dilakukan post-test observasi tindakan kewaspadan universal sudah menunjukkan peningkatan dimana semua peserta menutup spuit bekas pakai dengan satu tangan, dapat menggunakan peralatan pelindung diri dengan baik dan melakukan tindakan mencuci tangan dengan baik. Hal ini juga hampir sama dengan hasil penelitian Gurubacharya, Mathura, dan Karki (2003) tentang pengetahuan, sikap dan praktik tenaga kesehatan dalam mencegah cedera karena jarum suntik. Praktek mencuci tangan yang seyogyanya dilaksanakan oleh setiap peserta tidak dapat dilakukan karena tidak terdapatnya fasilitas cuci tangan dengan air mengalir di tempat pelatihan sehingga praktek mencuci tangan hanya dilakukan pada tiga orang peserta saja.

\section{Simpulan}

Simpulan dari kegiatan upaya peningkatan pelaksanaan tindakan kewaspadaan universal adalah adanya peningkatan pengetahuan dan sikap tenaga kesehatan di Puskesmas. Seluruh peserta antusias dan memberikan respon positif serta berdiskusi secara aktif dalam kegiatan ini. Upaya peningkatan pelaksanaan tindakan kewaspadaan universal bagi petugas Puskesmas Jatinangor Kab. Sumedang, Propinsi Jawa Barat" telah menunjukkan adanya peningkatan aspek pengetahuan, sikap, dan tindakan petugas dalam melaksanakan tindakan kewaspadaan universal. Berdasarkan hasil pre-test dan post-test diketahui terdapat peningkatan pengetahuan, sikap, dan tindakan petugas Puskesmas Jatinangor terhadap tindakan kewaspadaan universal. Dari aspek pengetahuan, 60\% peserta mendapatkan skor 100, dari aspek sikap hampir seluruh petugas (84\%) memiliki sikap mendukung terhadap tindakan kewaspadaan universal, dan tiga peserta yang melakukan post-test praktek tindakan kewaspadaan universal telah melaksanakan tindakan kewaspadaan universal dengan baik.

Berdasarkan hasil kegiatan pengabdian kepada masyarakat ini, ada beberapa saran yang dapat dilakukan antara lain, pimpinan puskesmas perlu melakukan monitoring terhadap seluruh petugas di Puskesmas Jatinangor agar tetap melaksanakan tindakan kewaspadaan universal dengan baik perlu adanya pelatihan dan penyegaran secara berkala tentang tindakan kewaspadaan universal, mengingat sarung tangan dan cuci tangan sangat penting dalam tindakan kewaspadaan universal, pihak puskesmas dan dinas kesehatan Kab. Sumedang diharapkan dapat menyediakan fasilitas cuci tangan dan sarung tangan yang memadai bagi petugas puskesmas.

\section{Daftar Pustaka}

Departemen Kesehatan RI. (2006). Situasi HIV/AIDS di Indonesia tahun 1997 - 2006. Depkes RI: Jakarta 
Dinas Kesehatan Kab. Sumedang (2006). Profil Kesehatan Kabupaten Sumedang, Sumedang.

Dinas Kesehatan Propinsi Jawa Barat (2018). Kasus HIV/AIDS di Jawa Barat Capai 21 Ribu. Diakses tanggal 7 November 2018.

http://www.jabarprov.go.id/index.php/news/24404/2017/08/09/Kasus-HIV-AIDS-di-JabarCapai-21-Ribu

Gurubacharya, D. L., Mathura, K. C., \& Karki, D. B. (2003). Knowledge, attitude and practices among health care workers on needle-stick injuries. Kathmandu University Medical Journal (KUMJ), 1(2), 91-4.

Janjua, N. Z., Razaq, M., Chandir, S., Rozi, S., \& Mahmood, B. (2007). Poor knowledgepredictor of nonadherence to universal precautions for blood borne pathogens at first level care facilities in Pakistan. BMC infectious diseases, 7(1), 81.

Kermode, M., Jolley, D., Langkham, B., Thomas, M. S., Holmes, W., \& Gifford, S. M. (2005). Compliance with Universal/Standard Precautions among health care workers in rural north India. American journal of infection control, 33(1), 27-33.

Li, L., Lin, C., Wu, Z., Guan, J., Jia, M., \& Yan, Z. (2011). HIV-related avoidance and universal precaution in medical settings: opportunities to intervene. Health services research, 46(2), 617-631.

Oktarina, O., Hanafi, F., \& Budisuari, M. A. (2009). Hubungan antara karakteristik responden, keadaan wilayah dengan pengetahuan, sikap terhadap HIV/AIDS pada masyarakat indonesia. Buletin Penelitian Sistem Kesehatan, 12(4).

Sadoh, W. E., Fawole, A. O., Sadoh, A. E., Oladimeji, A. O., \& Sotiloye, O. S. (2006). Practice of universal precautions among healthcare workers. Journal of the National Medical Association, 98(5), 722.

Sugiharti, S., Yuniar, Y., \& Lestary, H. (2014). Gambaran Kepatuhan Orang Dengan HivAids (Odha) Dalam Minum Obat Arv Di Kota Bandung, Provinsi Jawa Barat, Tahun 20112012. Jurnal Kesehatan Reproduksi, 5(2), 113-123.

World Health Organization (2007). Standard Precaution in Health Care. Diakses tanggal 5 Januari 2018. http://www.who.int/csr/resources/publications/EPR_AM2_E7.pdf

World Health Organization (2017). Summary of the Global HIV Epidemic. Diakses tanggal 7 November 2018. http://www.who.int/hiv/data/2017_summary-global-hivepidemic.png?ua=1.

World Health Organization (2017). Kajian Nasional Respon HIV di Bidang Kesehatan Republik Indonesia. Diakses tanggal 7 November 2018.

http://www.searo.who.int/indonesia/publications/hiv_country_review_indonesia_bahasa.pdf 